\title{
Evaluation of the Resistance of Mungbean Lines to Sprout Rot Caused by Pseudomonas species
}

\author{
Vijayanand Velusamy and Euiho Park*
}

School of Biotechnology, Yeungnam University, Gyeongsan 712-749, Korea

Received November 24, 2011 /Revised April 20, 2012 /Accepted June 26, 2012

\begin{abstract}
Mungbean sprout rot is one of the most serious problems of the commercial mungbean sprout industry. In this study, 70 strains of mungbean sprout rot pathogens were isolated from rotten sprouts at different time intervals. The pathogenicity of the isolated pathogens was tested. The highly pathogenic strain (YV-St-033) was identified as Pseudomonas sp. by 16S rRNA gene sequencing. In phylogenetic analysis, the YV-St-033 strain was grouped with $P$. mosselii, $P$. putita, $P$. fluorescens, $P$. entomophila, and $P$. lecoglossicida. The results of the 16S rRNA gene sequence analysis revealed that the YV-St-033 strain shared the highest sequence identity (more than 99\%) with the $P$. mosselii R10 strain. The mungbean lines of Yeungnam University germplasm were screened against the YV-St-033 strain. Based on the growth rate of the sprouts after 3 days of inoculation with the pathogen, the YV148 line was highly resistant to the pathogen. The remaining lines were either partially or fully infected. The highly resistant line YV 148 is suitable for future breeding programs due to their thin sprouts and fast growing nature.

Key words : Mungbean, Pseudomonas species, resistance screening, sprout rot, 16S rRNA gene sequence
\end{abstract}

\section{Introduction}

Mungbean sprout is one of the most popular vegetables. Mungbean sprout is also used as stuffing in the production of dumpling (mandoo) and as raw ingredient in the manufacture of Woodong (Chinese noodle) flakes. Mungbean protein is easily digested without flatulence. It is an important protein source for people in the cereal-based society. Since it shows a better quality compared to other sprouts, its consumption is expected to increase domestically and abroad as well. However, mungbean sprout is highly prone to decay and food sanitation is a major limiting factor for mass production up to consumption [8]. Mungbean sprout rot is one of the most serious problems of the commercial mungbean sprout industry. However, its causal agent has not been well understood yet. So far, only few experiments were carried out to prevent the rotting of mungbean sprouts at industrial level. Lee et al., [8] suggested a heat treatment technique for controlling of mungbean sprout rot. Han and Lee [3] identified Colletotrichum truncatum and C. gloeosporioides from mungbean plants for the first time in Korea. They also found that seed infestation rate was higher for $C$. truncatum, but lower for C. gloeosporioides. Previously, Kim et al., [5] identi-

*Corresponding author

Tel : +82-10-9357-2916, Fax : +82-53-810-4769

E-mail : ehpark1@ynu.ac.kr fied $C$ acutatum from mungbean sprout rot samples on market.

Comparatively, large number of researches was done on soybean sprouts like soybean rot caused by Pseudomonas putida [9], Erwinia carotova [10] and Pseudomonas syringae [4]. At industrial level severe sprout rot was reported during summer [12]. Lim et al [9] isolated Pseudomonas putida strain from rotten soybean sprouts. Differently expressed genes induced by Pseudomonas strain was observed in the resistant soybean sprout [4]. Considering the importance of mungbean sprouts, there is a need for understanding the characteristics of the causative pathogen and developing mungbean sprout-rot resistance variety.

\section{Materials and Methods}

The pathogen isolation, identification, and resistance screening were followed from previous Kang model [4]. For a period of one year rotten mungbean sprouts were collected from local markets and restaurants around Gyeongsan area in South Korea. From these rotten sprouts seventy strains of sprout rot pathogens were isolated under laboratory conditions. The isolated strains were cultured in NB broth $\left(3.0 \mathrm{~g} / 1\right.$ beef extracts and $5.0 \mathrm{~g} / 1$ peptone) at $28^{\circ} \mathrm{C}$. For inoculation to sprouts, all the 70 isolated pathogen strains were cultured until 0.5 of OD number at $600 \mathrm{~nm}$ using 
spectrophotometer. Mungbean seed purchased from local market was used for the preliminary screening of pathogen strains. The surface-sterilized local mungbean cultivar was germinated in petridish at $26^{\circ} \mathrm{C}$ in the dark for 2 days. Seedlings were imbibed for 2 hours in NB medium with $5 \times 10^{8} \mathrm{cfu} / \mathrm{ml}$ of pathogen strains and then washed with sterilized water. The inoculated sprouts were observed for rotting symptoms for a period of 3 days after infection with the pathogen strains. Three replications were made and the average hypocotyledon length of inoculated and non-inoculated sprouts was then calculated [4]. The same procedure was repeated three times and the pathogenicity level based on visibility of rotten symptoms and growth ratio were observed. Then one highly pathogenic strain (YV-St-033) was selected for further analysis. The highly pathogenic strain was then screened against forty eight geographically different mungbean lines obtained from Yeungnam University germplasm bank, by following the same inoculation techniques.

\section{Data analysis}

$16 \mathrm{~S}$ ribosomal RNA gene sequencing was conducted by Solgent Co., Ltd., South Korea using single colony PCR to identify the taxonomical position of the YV-St-033 strain. The sequences were analyzed using the Classifier of Ribosomal Database Project (RDP) on the website (http://rdp.cme.msu.e- du). Homology comparison of the complete 16S rRNA gene sequence of YV-St-033 was performed by running it through the BLAST database on NCBI (http://www.ncbinlmnih.gov/). The phylogenetic tree was inferred using the MEGA 4.0 software package [11].

\section{Results and Discussion}

YV-St-033's taxonomic status could be determined directly to be as follows: Bacteria (domain), Proteobacterria (phylum), Grammaproteobacteria (class), Pseudomonadales (order), Pseudomonadaceae (family), and Pseudomonas (genus).

On the item of SeqMatch, the S_ab score, which indicates the extent of similarity between the 16S rRNA gene of YV-St-033 with that of 20 sequences of identical strains from the RDP database (Table 1). YV-St-033 was considered to have highest sequence similarity with those Pseudomonas strains for which S_ab scores were between 0.991 and 0.980 . Further, of the 20 strains, maximum of 6 strains were identified to be Pseudomonas mosselii with a maximum S_ab score of 0.991 for the Pseudomonas mosselii R10 strain (Gene bank ID DQ073452). And among the remaining 14 strains 5 of them were Pseudomonas sp, 3 were uncultured bacterium, 2 were Pseudomonas putida and individual strains of Pseudomonas cf. monteilii, Pseudomonas entomophila and

Table 1. Similarity between the 16S rRNA gene of YV-St-033 strain and that of 20 other strains

\begin{tabular}{|c|c|c|}
\hline ID orientation & Strains & S_ab score \\
\hline S000538861 & Pseudomonas mosselii, R10, DQ073452 & 0.991 \\
\hline S000559094 & Pseudomonas mosselii, R16, DQ095881 & 0.983 \\
\hline S000388736 & Pseudomonas cf. monteilii, 9, AF181576 & 0.980 \\
\hline S000653351 & Pseudomonas sp. PALXIL09, DQ411819 & 0.980 \\
\hline S000711291 & Pseudomonas mosselii, WAB1873 & 0.982 \\
\hline S000722217 & Pseudomonas sp. PALXIL12, DQ821413 & 0.980 \\
\hline S000722496 & Pseudomonas mosselï, E1, DQ837709 & 0.986 \\
\hline S000774933 & Pseudomonas sp. OCR3, AB240202 & 0.980 \\
\hline S000776619 & Pseudomonas entomophila, 2P25 & 0.980 \\
\hline S000824562 & Pseudomonas putida, J312, EF203210 & 0.980 \\
\hline S000841838 & Pseudomonas mosselii (T), CIP 105259 & 0.986 \\
\hline S000965129 & Pseudomonas sp. RW9S1, AM911667 & 0.980 \\
\hline S001293557 & Serratia marcescens subsp. Marcescens & 0.980 \\
\hline S001577106 & Pseudomonas sp. PCSAS2-22, GQ284542 & 0.983 \\
\hline S001589594 & Pseudomonas mosselii, CCC77 & 0.986 \\
\hline S002034049 & Pseudomonas putida, LW, GU377179 & 0.986 \\
\hline S002078115 & uncultured bacterium, ncd505b08c1 & 0.980 \\
\hline S002108460 & uncultured bacterium, ncd820f05c1 & 0.980 \\
\hline S002234792 & Pseudomonas sp. KN4, HQ231949 & 0.980 \\
\hline S002269504 & uncultured bacterium, nby564g07c1 & 0.986 \\
\hline
\end{tabular}




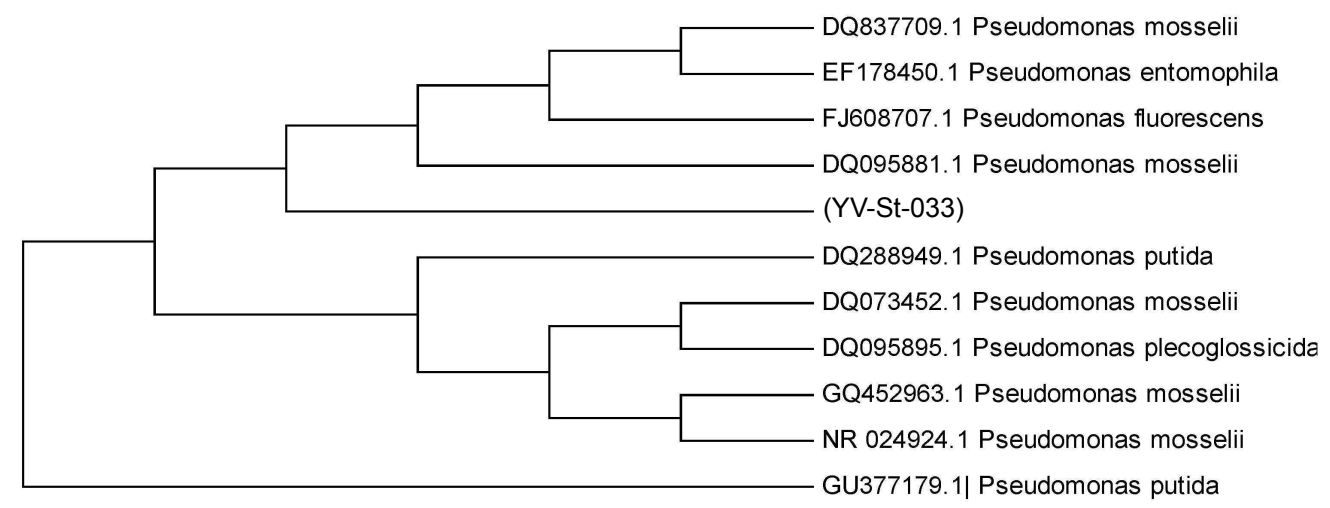

Fig. 1. Phylogenetic tree obtained from 16s rRNA gene analysis.

\section{Serratia marcescens subsp. Marcescens.}

By using the MEGA4 software, a phylogenetic tree (Fig. 1) was obtained from the nucleotide sequence alignment of isolated strain and its sequence identities. From the phylogenetic tree analysis, the isolated strain was found between P. mosselii and P.putida strains. This shows that the pathogenicity of Pseudomonas species on mungbean sprouts.

According to the bacterial taxonomists, strains with $16 \mathrm{~S}$ rRNA gene sequence homology higher than $99 \%$ can be identified as the same species. And, if the species have less than $98 \%$ sequence homology, they are different species that belong to the same genus. Less than $95 \%$ sequence homology implies that the species belong to different genera $[1,2,3]$. Therefore, the isolated strain (YV-St-033) was confirmed to be Pseudomonas mosselii R10 strain with the highest S_ab score of 0.991 and gene sequence homology compared to other strains. To the best of our knowledge, this is the first report of Pseudomonas mosselii rot in mungbean sprouts.

\section{Pathogenicity test}

In order to identify the resistant mungbean lines, 3 days old sprouts from 48 mungbean germplasm lines were examined against the isolated Pseudomonas mosselii R10 strain [9]. The hypocotyl growth rate of pathogen inoculated sprout ranged from 1.4 to 10.1. Most of the screened samples were susceptible to the pathogen and the low growth rate was observed where the rotten symptoms were visible. The growth rate of the most accessions ranged between 1.4 to 5, mostly below 2. However, the accession number YV 148 whose growth rate above 10 was found without any visible rotten symptom. The effect of pathogen on 4 different mungbean lines was shown (Fig. 2). The growth rate of inoculated and non-inoculated YV174, YV232, YV339 and YV 148
Table 2. Growth rate of the mungbean lines after inoculation with the YV-St-033 strain

\begin{tabular}{cccc}
\hline \multirow{2}{*}{$\begin{array}{c}\text { Accession } \\
\text { No. }\end{array}$} & \multicolumn{2}{c}{$\begin{array}{c}\text { Average hypocotyl length }(\mathrm{cm}) \\
\text { after } 72 \mathrm{hr}\end{array}$} & $\begin{array}{c}\text { Growth } \\
\text { rate }\end{array}$ \\
\cline { 2 - 3 } & Non-Inoculated & Inoculated & \\
\hline YV174 & 6.0 & 2.0 & 1.5 \\
YV232 & 7.6 & 3.0 & 1.7 \\
YV339 & 9.1 & 6.2 & 3.1 \\
YV148 & 13.1 & 11.8 & 10.1 \\
\hline
\end{tabular}

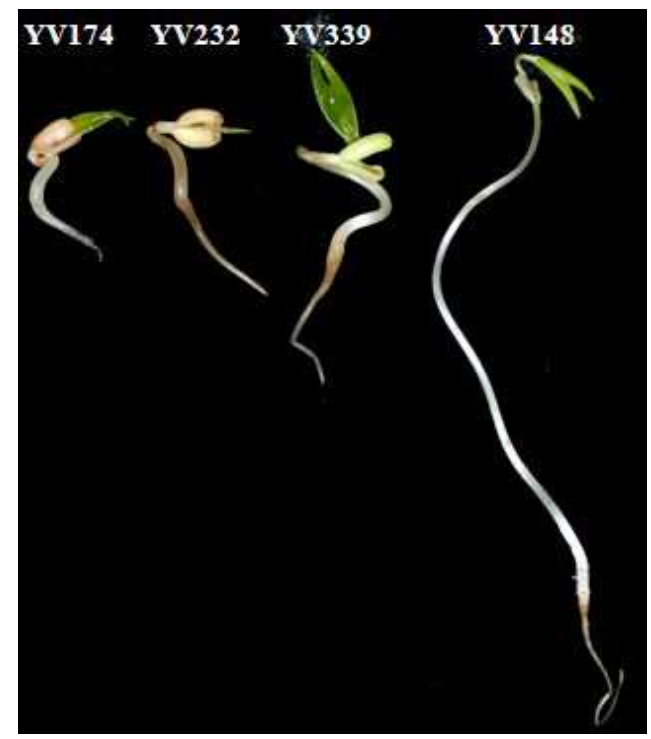

Fig. 2. The effect of pathogenic strain (YV-St-033) on four different mungbean lines YV174, YV232, YV339 and YV148 after 3days of infection.

accessions were tabulated (Table 2). From this it was clear that the accession YV148 with high growth rate and without rotten symptoms possess resistance to the YV-St-033 strain.

It was also noted that the highly resistant accession YV 148 was suitable for future breeding programs due to their 
thin sprouts and fast growing nature when compared to other accessions. The small seeds and thin sprouts were preferred by industrial sprout producers. It is generally accepted that sprout yield is greater when smaller seeds are germinated [7]. This research suggests the line YV148 is highly suitable for future pathogen screening process and industrial sprout production because of its unique slim sprouts, fast growing nature and sprout-rot resistance. For sprout production Kwon et al., [6] suggested that less seed weight is a desirable character. Thus, the line YV148 with lesser seed weight can be effectively utilized for industrial sprout productions.

\section{Acknowledgement}

This work was carried out with the support of "Cooperative Research Program for Agriculture Science \& Technology Development (Project No. PJ907034)" Rural Development Administration, Republic of Korea.

\section{References}

1. Devereux, R., He, S. H. and Doyle, C. L. 1990. Diversity and origin of Desulfovibrio species: phylogenetic definition of a family. J. Bacteriol. 172, 3609-3619.

2. Fry, N. K., Warwick, S. and Saunders, N. A. 1991. The use of $16 \mathrm{~S}$ ribosomal RNA analyses to investigate the phylogeny of the family Legionellaceae. J. Gen. Microbiol. 137, 12151222.
3. Han, K. S. and Lee, D. H. 1995. Identification and etiological characteristics of Anthracnose fungi isolated from soybean, small red bean and green bean. Korean J. Plant Pathol. 11, 30-38.

4. Kang, S. G., Cha, H. W., Chang, M. U. and Park, E. H. 2003. Identification of differentially displayed genes of a Pseudomonas resistant soybean (Glycine max). Plant Pathol. J. 19, 239-247.

5. Kim, D. K., Lee, S. C., Kang, J. H. and Kim, H. K. 2003. Colletotrichum disease of mugbean sprout by Colletotrichum acutatum Plant Pathol. J. 19, 203-204.

6. Kwon, S. H., Lim, K. H. and Kim, J. R. 1972. Studies on diversity of seed weight in Korean soybean land races and wild soybean. Korean J. Breed 4, 70-74.

7. Kwon, S. H., Lee, Y. I. and Kim, J. R. 1981. Evaluation of important sprouting characteristics of edible soybean sprout cultivars. Korean J. Breed 13, 202-206.

8. Lee, J. H., Han, K. S., Kim, T. H., Bae, D. W., Kim, D. K. and Kang, J. H. 2007. Effective heat treatment techniques for control of mungbean sprouts rot, incorporable into commercial mass production. Plant Pathol. J. 23, 174-179.

9. Lim, J. S., Do, K. S., Lee, D. S., Kang, S. G., Suh, S. G. and Park, E. H. 2008. Identifications of a sprout-rot pathogen Pseudomonas species SN239 and selection resistant soybean line. J. Life Sci. 18, 1771-1774.

10. Park, J. C., Song, W. Y. and Kim, H. M. 1996. Occurrence of bacterial soft rot of soybean sprout caused by Erwinia carotovora sub sp. carotovora. Korean J. Plant Pathol. 13, 13-17.

11. Tamura, K., Dudley, J., Nei, M. and Kumar, S. 2007. MEGA4: molecular evolutionary genetics analysis (MEGA) software version 4.0. Mol. Biol. Evol. 24, 1596-1599.

12. Yun, S. C. and Kim, Y. H. 2003. Pathogenic bacteria causing rot in commercial soybean sprout cultivation. Kor. J. Crop Sci. $48,113-119$.

\section{초록 : Pseudomonas sp. 유래 녹두 부패병의 병 저항성 녹두 계통 검정 \\ 벨루사미비제야난드 · 박의호* \\ (영남대학교 생명공학부)}

녹두나물(숙주나물)은 국내뿐만 아니라 세계적으로도 널리 이용되고 있는 채소다. 그런데 녹두나물 재배를 하 는 과정에서 발생되는 녹두나물 무름병은 녹두나물 생산량은 물론 품질을 심각하게 저하시킨다. 본 연구에서는 녹두나물 부패 조직으로부터 70 계통의 병원균을 분리하였으며, 각 병원균의 병원성을 검정하였다. 그 가운데 강 한 병원성을 가진 Pseudomonas 균류의 계통 YV-St-033를 확인하여 선발하였으며, 분리된 병원균계의 $16 \mathrm{~S}$ rRNA 유전자 염기서열을 분석하고 유전학적 유연관계를 분석하였다. YV-St-033는 P. mosselii, P. putita, P. fluorescens, P. entomophila, P. lecoglossicida 등의 종이 속한 그룹으로 확인이 되었으며, Pseudomonas mosselii R10 strain과 가장 높은 염기서열 identity (약 99\%)를 보였다. 또한 YV-St-033 strain을 이용하여 영남대학교에서 보유하고 있는 녹 두 유전자원들에 대해 녹두나물 무름병 저항성을 검정하였다. 3 일간 배양한 녹두에 병원균을 접종하고 녹두의 생장율을 비교한 결과 YV148 line에서 높은 저항성이 확인되었으며, 그 외 녹두 계통에서도 부분적인 저항성을 나타내었다. 숙주나물 무름병에 저항성을 보인 YV 148 계통은 나물이 가늘고 연하고 생장율이 우수하여 앞으로 품종 육종의 좋은 재료로 활용될 수 있을 것으로 판단되었다. 